\title{
THE EU ENLARGEMENT. HOW TO BE LIKE THE IRISH AND NOT THE GREEK?
}

\author{
Tahir Mahmutefendic ${ }^{1}$
}

date of paper receipt:

02.11.2019.

Review Article date of sending to review:

05.11.2019.

doi: 10.2478/eoik-2019-0021 date of review receipt:

13.11.2019.

UDK: 341.217.02(4-

672EU):338.124.4(495+416)

${ }^{1}$ SSST - Sarajevo School of Science and Technology and SSST Grammar School, Bosnia and Herzegovina

\begin{abstract}
Apart from the former EFTA members (Iceland, Lichtenstein, Norway and Switzerland) and a few former republics of the Soviet Union (Bjelorussia, Moldova and Ukraina) the countries of the Western Balkans are the only European states outside of the European Union. They are very keen to join the Union. The Balkans have always been the poorest part of Europe. The appeal of the wealthy European Union is apparent. Access to the largest market in the world, investment, modern technologies and generous regional funds give a hope that by joining the EU the Western Balkans countries will join the rich club. At the moment performance of the Western Balkan countries does not guarantee that they will become rich by joining the European Union. Their current production and trade structure makes it likely that the Western Balkan countries will be locked in inter-industry trade in which they will export products of low and medium technological and developmental level and import products of high technological and developmental level. This might lead to divergence rather than convergence between them and the European Union. In other to overcome this problem the Western Balkan countries need to conduct radical reforms in the public sector, fiscal policy, industrial trade and investment policy. They also need to tackle corruption, simplify administrative procedure, strenghten property rights and the lawful state. All this with the aim to change economic structure and shift from achievements of the second and third to fourth technological revolution. Only if these reforms are successfuly implemented the Western Balkan countries can hope to avoid the Greek scenario and possibly experience the Irish scenario.
\end{abstract}

\section{Keywords:}

Gravity Model, Ricardian Theory of Comparative Advantage, H-O-S Theory, Consumer Preference Theory, Inter-industry Trade, Intra-industry Trade, EU Core, EU Periphery 


\section{INTRODUCTION}

One of the most frequently mentioned topics in the media is further EU enlargement. It refers to the largest part of Europe which has remained outside of the biggest market in the world; theWestern Balkans comprises Serbia, Bosnia and Herzegovina, Montenegro, Northern Macedonia, Albania and Kosovo. Five of these six countries were part of the former Yugoslavia.

During the 1980s Yugoslavia experienced economic stagnation, accompanied by hyperinflation, high unemployment and soaring external and internal debt. This precipitated its bloody dissolution, although frictions and tensions existed between its constituent units, republics and autonomous provinces, even before 1980s in a more favourable economic environment

The main conflict in the former Yugoslavia revolved around a rivalry between the largest and politically strongest Serbia and most developed and richest Slovenia and Croatia. Serbia complained that it was economically exploited by Slovenia and Croatia, who in turn were unhappy because of alleged Serbian political hegemony.

Conventional explanation of tensions and eventual break-up of Yugoslavia was that Serbia, on one hand, and Slovenia and Croatia on the other, belong to different civilisations. This theory looks superficial since the Czech Republic and the Slovak Republic belong to the same civilisation and still parted. More plausible explanation seems to be the fact that unlike Italy and Germany, where Piedmont and Prussia provided political and military leadership and were the most developed parts of the two states, in Yugoslavia politically and militarilly strongest Serbia was not economically and culturally most developed. Its leadership was dreaded by Slovenia and Croatia, fearing that it could drag them down and increase the gap between them and Western Europe. Serbia, on the other hand, did not want to accept a leadership of the two most developed republics, fearing that it would increase the gap between them in the level of development. The other three republics feared political subjugation by Serbia and economic exploatation by Slovenia and Croatia.

In such a situation none was happy with the common state. This includes Serbia, which paid a lip service to a Yugoslav unity. In fact, Serbia was the first to secede from Yugoslavia from the legal point of view. The Serbian constitution, passed on the 28th November 1990, stated that the federal constitution and federal laws are valid on the territory of Serbia only if they do not contradict republican constitution and republican laws.

As independent states all the former Yugoslav republics have been enthusiastic to join the European Union. They have been more than willing to accept the leadership from Brussels and to surrender a good part of their sovereignty to various centres of power and to unelected and unaccountable bureaucrats and technocrats ( Many political and economic commentators and analysts state that Croatia had more sovereignty as a republic in the Yugoslav federation than as an independent state within the European Union).

So, what was wrong with Yugoslavia and what is right with the European Union? Apparent reason, obvious even to ordinary citizens is the level of development. The European Union consists of a highly developed countries with a high incomes per capita. A membership in the European Union will provide an access to the largest market in the world, state-of-art technologies, investment, new organisational and management methods, and above all generous regional funds. This would enable them to join the rich club.

This work will try to critically evaluate the accuracy of such thinking.

The work is divided into four parts. The first part presents some relevant facts related to the European Union. The second part analyses the relevance of the gravity model in explanation of the core and periphery of the European Union. The third part compares Southern and Eastern peripheries of the European Union with Northern and Western peripheries of the European Union. The fourth part briefly analyses economic performance of the Western Balkan States and measures needed to catch up with the European Union.

The EU - Some Relevant Facts 


\subsection{POPULATION}

After Croatia joined the European Union in July 2013 the population of the Union exceeded half a billion. Countries of the European Union differ significantly according to their size and population. They can be divided into the following groups:

Very big countries have the population of 35 million or more. In the EU there are six of these Germany, the UK, France, Italy, Spain and Poland. Germany is the biggest country in the group, more than two times greater than the smallest one, Poland. The total population of this groups accounts for about three quarters of the population of the Union.

Big countries comprise only two members; Romania, with a population of 21.8 million and the Netherlands with a population of 16 million.

The medium nations have populations between 8 and 11 million. There are eight countries in this group; Greece, Portugal, Belgium, the Czech Republic, Hungary, Sweden, Austria and Bulgaria.

The small nations have populations between 1,4 million and 4 million. This group includes Denmark, Slovakia, Finland, Ireland, Lithuania, Latvia, Slovenia and Estonia.

The tiny nations have populations below one million. This group includes Cyprus, Luxembourg and Malta.

\subsection{INCOMES}

Income per capita varies significantly in the EU member states. This is often a problem in setting common policies.

According to the average income EU countries can be classified into three groups - high, medium and low. Luxembourg is by far the richest nation with the average income exceeding the one in Sweden and France together.

The high-income category is defined as income above the EU average, which amounted to 25,900 euros in 2008. This group includes 12 of the EU nations (Luxembourg, Ireland, the Netherlands, Austria, Sweden, Denmark, Finland, Belgium, the UK, Germany, France and Spain).

The medium income category includes countries whose GDP per capita was between 10,000 and 25,500 euros. This group includes Italy, Greece, Portugal, Cyprus, Slovenia, Malta, the Czech Republic, Hungary, Slovakia, Lithuania, Poland, Latvia, Estonia and Croatia.

Low-income group comprises only two countries, Bulgaria and Romania, whose income is slightly below 10,000 euros.

\subsection{SIZE OF EU ECONOMIES}

Combining population and average income we arrive at size of economy. According to this criterion all the EU nations could be divided into four categories; big, small, tiny and miniscule.

Big countries include Germany, the UK, France, Italy, Spain and the Netherlands. These six countries account for more than 80 per cent of the GDP of the whole EU.

Small economies account for between 1 and 3 per cent of the EU output. This group consists of Sweden, Belgium, Austria, Denmark, Poland, Finland, Greece, Portugal, Ireland and Romania. Tiny economies are those that account for less than 1 per cent of the total. These are the Czech Republic, Hungary, the Slovak Republic, Luxembourg, Slovenia, Lithuania, Bulgaria and Cyprus. Miniscule are countries whose contribution to total GDP is less than 0.1 per cent. Latvia, Estonia and Malta are the nations in this category.

The 2004 enlargement had very little impact on the overall size of the EU economy. The ten newcomers' economies amount to only 5 per cent of the EU 15's GDP, with Poland alone accounting for about half of this 5 per cent. (Baldwin \& Wyplosz 2009) 


\section{GRAVITY MODEL AND THE EU CORE}

Economics borrowed many concepts from Physics. One of them is a Gravity Model. In Physics two bodies are more attracted to each other if their weight is similar and if they are close to each other. The same principle applies in Economics. Two countries are more „attracted“ to each other (have more intensive trade and other economic links) if their weight is more similar(level of development measured by GDP per capita) and if distance between them is smaller. This relationship could be expressed as a function:

$E . L=f(Y a, Y b)(+), d(-)$,

Where E.L. stands for trade, investment and other economic links between countries A and B, Ya and $\mathrm{Yb}$ are incomes per head in countries $\mathrm{A}$ and $\mathrm{B}$ and $\mathrm{D}$ is distance between countries $\mathrm{A}$ and $\mathrm{B}$. „Weight“ (GDP per capita) is directly and distance inversely related to economic links.

The following table shows GDP per capita in PPP terms for the EU core countries:

Table 1. GDP per capita (PPP) in dollars in the EU core countries

\begin{tabular}{|c|c|c|}
\hline EU Core Countries & $\begin{array}{c}\text { GDP per capita(PPP) in } \\
\text { dollars }\end{array}$ & Index \\
\hline Austria & 54,084 & 141 \\
\hline Belgium & 49,705 & 129 \\
\hline France & 47,113 & 124 \\
\hline Germany & 54,984 & 143 \\
\hline Luxembourg & 112,622 & 294 \\
\hline The Netherlands & 59,105 & 155 \\
\hline EU Average & 38,274 & 100 \\
\hline Core EU Average & 52300 & 136 \\
\hline
\end{tabular}

Source: World Bank International Comparison Program Data 2019 - international dollars. Last row and last column are the author's calculations.

The table reveals three things. Firstly, the EU core has higher GDP per capita compared to the EU average. Secondly, every individual core country has above average GDP per capita. Thirdly, core countries have a similar GDP per capita. If we exclude Luxembourg, whose size is negligible, the most developed the Netherlands has GDP per capita only 25 per cent higher than the least developed France. The core countries, have therefore, a similar „weight“.

The core countries are situated in proximity with each other. Germany is in the centre of Europe and borders most of the other countries. The greatest distance is between Austria and the Benelux countries, but they are separated only by Germany. The gravity model, therefore, explains why the core countries are more developed than the EU average.

3.The EU peripheries

According to the gravity model it is expected that peripheries of the EU are less developed than its core. There are four peripheries in the EU; Southern, Eastern, Northern and Western.

Southern periphery includes PIGS countries - Portugal, Italy, Greece and Spain. After sixth enlargement in 2004 it also comprises Cyprus and Malta. All these countries have GDP per capita lower than the EU core countries: 
Table 2. GDP per capita (PPP) in the EU Southern Periphery

\begin{tabular}{|c|c|c|}
\hline Country & GDP per capita & Index (EU core = 100) \\
\hline Cyprus & 41,572 & 78 \\
\hline Greece & 30,522 & 57 \\
\hline Italy & 40,737 & 76 \\
\hline Malta & 47,061 & 91 \\
\hline Portugal & 33,409 & 64 \\
\hline Spain & 42,120 & 79 \\
\hline EU core & 53,200 & 100 \\
\hline
\end{tabular}

Source: World Bank International Comparison Program Data 2019 - international dollars. Last row and last column are the author's calculations.

In this group of countries the gravity model is best verified in the case of the poorest country, Greece. Greece joined the EEC in 1981. Its membership in the community was forced by the conservative New Democracy and strongly opposed by the Socialist and Communist party. As a member of the EEC Greece experienced relative retardation in its development. In 1981 its GDP per capita stood at 77 per cent of the community's average. It slipped to 62 per cent in 1990. Some authors find the explanation for this in Geography and the fact that Greece was involved in inter-industry instead of intra-industry trade with the other members of the community. (Petrakos \& Totev - editors, 2001) Greece's plight has been intensified after the introduction of the euro. Greece's „qualified“ for the euro in May 2000. After the credit crunch it transpired that the Greek government of George Papandreou struck a deal called AEOLOS, named after the Greek god of the winds, with Goldman Sachs. Goldman Sachs helped Greece to borrow billions recording them as a financial derivative "swap" through financial creative engineering. Goldman Sachs received for that service a fee of $\$ 300$ million. Greece promised a fiscal deficit of 3.7 per cent of GDP in 2009. It was actually four times higher. (Mahmutefendic 2015)

Austerity measures which accompanied bail out packages included spending cuts, tax increases and privatisation. The public sector wages were reduced by 20 per cent. The so called 13 th and 14 th salary were to be replaced by an annual lump sum the size of which varies with the wage. Wages and salaries were frozen for three years. Employment in the public sector was reduced. For every worker hired, five were retired. Unemployment benefits were cut, and poverty support schemes that had been put in place in December 2009 were suspended. The cuts were spilled into the private sector. (Ibid)

Austerity measures had two aims; to reduce fiscal deficit and public debt and to improve competitiveness. It was assumed that slashing salaries and wages would bring down nominal labour costs and close a competitiveness gao between Greece and Germany and to a lesser extent the other core countries. The logic went that the release of resources from the public sector as a result of spending cuts, as well as the reduction in private spending brought on by tax increases, would reduce aggregate demand and increase unemployment. The resulting excess supply in the economy and increased pressure to win business and keep jobs would lower costs, prices and wages and improve competitiveness. This was an outright deflationary policy applied in the 1930's which proved wanting. This time it acquired a new euphemism, „internal devaluation“.

This process of "internal devaluation“ was extremely slow, considering the fact that the competitiveness gap between Greece and Germany was in a range of 30-40 per cent. Although the competitiveness gap decreased in 2013, the price in soaring fiscal deficit, public debt and unemployment was heavy. (Ibid)

Eastern periphery comprises former communist countries; Bulgaria, Croatia, the Czech Republic, Estonia, Hungary, Latvia, Lithuania, Poland, Romania, Slovakia and Slovenia. All these countries 
have lower GDP per capita than the EU core countries. Also, they are less developed than the countries of the Southern periphery.

Table 3. GDP per capita (PPP) in the countries in Eastern EU periphery

\begin{tabular}{|c|c|c|}
\hline Country & GDP per capita & Index (EU core =100) \\
\hline Bulgaria & 24,577 & 47 \\
\hline Croatia & 27,664 & 53 \\
\hline The Czech Republic & 39,337 & 76 \\
\hline Estonia & 36,346 & 69 \\
\hline Hungary & 33,409 & 64 \\
\hline Latvia & 31,215 & 59 \\
\hline Lithuania & 37,162 & 71 \\
\hline Poland & 33,472 & 64 \\
\hline Romania & 27,753 & 53 \\
\hline Slovakia & 37,268 & 71 \\
\hline Slovenia & 38,841 & 74 \\
\hline EU core average & 52,300 & 100 \\
\hline
\end{tabular}

Source: Wordl Bank International Comparison Program Data 2019 - international dollars. Last row and last column are the author's calculations.

In addition to the gravity model argument part of explanation of a relative poverty of the Eastern periphery lies in its communist past. The argument goes that the communist countries performed less well than their counterparts in the Western Europe. While this is undoubtedly true for the Czech Republic and to a lesser extent to Slovakia, it is questionable whether this argument is valid for the other countries, especially for the Balkan ones. The Balkans have always been the poorest part of Europe, so historical factors might prevail in the explanation of its relative backwardness. Northern periphery comprises three Scandinavian countries; Sweden, Denmark and Finland. The first two countries have GDP higher and Finland lower than the EU core.

Table 4. GDP per capita (PPP) in the countries in the Northern EU periphery

\begin{tabular}{|c|c|c|}
\hline Country & GDP per capita & Index (EU core $=100)$ \\
\hline Sweden & 54,474 & 104 \\
\hline Denmark & 54,564 & 104 \\
\hline Finland & 48,221 & 93 \\
\hline EU core & 52300 & 100 \\
\hline
\end{tabular}

Source: World Bank International Comparison Program Data 2019 - international dollars. Last row and last column are the author's calculations.

Finland fell behind and the other two countries diminish its advantage compared to the EU core. Explanation for higher level of development in the Northern periphery usually is found in the Weberian thesis. (A thesis espoused by the German sociologist Max Weber in his book 'The Protestan Ethics and the Spirit of Capitalism', according to which the Protestant nations are best suited to the capitalist models of economy and society. Weber found the explanation for his thesis in the fact that Protestantism, more than other confessions, inspires hardwork, parsimony and devotion to a chosen job. He linked the latter with a word which means profession, a calling. The 
word 'call' in English and 'Beruf' in German have stronger connotations than 'vocation' in French, or 'vocazione' in Italian, two languages of non-Protestant countries.)

Western Periphery consist of only two countries; the UK and Ireland. The UK fell behind and has a lower GDP per capita compared to the EU core. Irish GDP per capita by far exceeds the EU core average.

Table 5. GDP per capita (PPP) in the countries in the Western EU periphery

\begin{tabular}{|c|c|c|}
\hline Country & GDP per capita & Index (EU core = 100) \\
\hline The United Kingdom & 47,042 & 90 \\
\hline Ireland & 81,686 & 156 \\
\hline EU core & 52300 & 100 \\
\hline
\end{tabular}

Source: World Bank International Comparison Program Data 2019 - international dollars. Last row and last column are the author's calculations.

Ireland is the only EU member whose GDP was lower than average GDP of the EU core when it joined the EEC and now by far exceeds the Union's average. In 1980, seven years after joining the EEC, Irish GDP per capita stood at 7,000 international dollars while all the other EU core countries had GDP per capita exceeding 10,000 international dollars. Ireland experienced a vigorous growth from 1984 to 2007 . This growth was interrupted by the Great Recession and a sovereign debt crisis, but it was resumed after a several years. Ireland is an open economy (6th on the Index of Economic Freedom)and ranks 5th of 187 in the IMF table and 6th of 195 in the World Bank table according to GDP per capita. (World Economic Outlook 2019) Foreign owned multinational companies play a decisive role in Irish prosperity, making up 14 of the top 20 firms (by turnover), employing 23 per cent of the private sector labour-force and paying 80 per cent of corporation tax collected. The Irish economy is knowledge economy, focused on services into high-tech, life sciences, financial services and agrobusiness including agrifood. (Ibid)

4.Is it possible to be Irish and not to be Greek?

If countries in the Western Balkans join the EU they will make a fifth periphery.

Table 6. GDP per capita (PPP) in the Western Balkans countries

\begin{tabular}{|c|c|c|c|}
\hline Country & GDP per capita & Index (EU core = 100) & Index (EU average = 100) \\
\hline Albania & 14,143 & 27 & 36 \\
\hline $\begin{array}{c}\text { Bosnia and } \\
\text { Herzegovina }\end{array}$ & 14,291 & 27 & 36 \\
\hline Montenegro & 19,734 & 37 & 51 \\
\hline $\begin{array}{c}\text { Northern } \\
\text { Macedonia }\end{array}$ & 16,253 & 31 & 41 \\
\hline Serbia & 17,076 & 33 & 44 \\
\hline EU core & 52,300 & 100 & 100 \\
\hline EU average & 38,784 & 100 & 100 \\
\hline
\end{tabular}

Source: World Bank International Comparison Program Data 2019 - international dollars. Last row and last column are the author's calculations.

The Western Balkans is the least developed region in Europe. Its GDP per capita is far less than GDP of the EU average. Only Montenegro reached half of the GDP per capita of the EU average. The Western Balkans fairs even worse in comparison with the EU core. Most countries have GDP 
which is in range between $1 / 4$ and $1 / 3$ of the EU core. The Balkans have always been the poorest region in Europe, so historical factors prevail in explanation of its backwardness.

Professor Vjekoslav Domljan list the characteristics of the economy of Bosnia and Herzegovina, most of which apply to the other Western Balkan countries:

GDP and the standard of living are amongs lowest in Europe;

High rate of unemployment which is amongst biggest in the world. As a result there is a strong outflow of a highly qualified workforce (brain drain) abroad;

Suboptimal growth rates of GDP, which do not contribute to a significant decrease in unemployment rate;

High macroeconomic imbalances reflected in large balance of payments deficits and to a lesser extent budget deficits. Macroeconomic imbalances are result of the fact that Bosnia and Herzegovina is one of the rare countries which records a negative rate of domestic savings and that national savings is positive only owing to remittances from abroad, but it is insufficient to cover investment; The lowest degree of computerisation and digitalisation in Europe;

Unfavourable economic structure, mainly based on the achievements of the Second Industrial Revolution;

Unfavourable production and export structure, dominated by low or medium technological content, with the exception of antibiotics created at Bosnalijek;

The greatest production of negative externalities in Europe, which is a logical consequence of the aforementioned characteristics expressed in the Kuznets' U-curve;

Overblown public sector, which is the biggest employer and the strongest pillar of the power of ethno-cartels:

Too heavy burdened private sector by taxes and contributions, which leads to „crowding-out“ and an informal economy which accounts for 25 per cent of GDP;

A bad tax structure, dominated by indirect regressive taxes;

Health and pension system, snowed under by unfavourable ratio between active and inactive population. This ratio is 1.13:1, while in the communist Bosnia and Herzegovina it was 2.8:1. (Domljan 2018)

To this list one could add corruption, a red tape, complicated procedure in registering new firms, weak protection of property rights and a lack of lawful state.

If Bosnia and Herzegovina and the other Western Balkan countries join the EU with such or similar performances they will be locked in inter-industry trade (Kos 1998) in which they will export products of low to medium technological and developmental level and import products of a high technological and developmental level. (Domljan 2018). This will turn the Western Balkan countries into economic colonies of the European Union and increase the gap in the level of development between them.

In order to avoid the Greek scenario and try to play the Irish scenario Professor Vjekoslav Domljan suggests the following:

Create vision, strategy and development strategy;

Significantly decrease widespread corruption and strengthen contract enforcement through enhancement of the lawful state;

Release creative energy of entrepreneurs through creation of the market economy from the bottom. In order to achieve this fiscal policy should be radically changed, through fiscal devaluation and increase of direct taxes, especially income tax and property tax;

Enhance domestic competitiviness and not to expose domestic producers to unrestrained import liberalisation;

Introduce new financial institutions and financial instruments and adequate regulation and supervision of financial markets;

Significantly increase investment in research and development, which currently stands at paltry 0.15 per cent of GDP; 
Modernise educational system by abandoning rote learning and its replacement by problem solving. Also, educational system should be unified and liberated from ethno-national parochialisms;

Introduce softwares and robots in production, which will help transformation of the economy from second and third to fourth technological revolution;

Change the structure of public expenditure by increasing productive public expenditures, such as investment in research and development and infrastructure;

Support development of value chains and clusters of production by linking entrepreneurs, innovators, investors and exporters;

Conduct an adequate price policy and its stabilisation using merchadise reserves. (Domljan 2018) Experience of countries which started their take-off from much lower level of development, particularly the Asian Tigers, show that implementation of these measures can create modern economy and achieve high income. Governing elites in the Western Balkans pay a lip service to these reforms, but are reluctant to implement them. Probably because they would erode their power and endanger their vested interests.

Future will show whether the Western Balkans will experience Greek or Irish scenario.

\section{CONCLUSION}

The European Union consists of a core and four peripheries; Southern, Eastern, Northern and Western. The Southern and Eastern peripheries are less developed than the core. The Northern periphery is more developed than the core. In the Western periphery the UK fell behind, but Ireland is more developed than the core.

There are two conspicious experiences after joining the EU. Greece experienced relative retardation. Ireland joined at GDP lower than the core, but owing to a vigorous growth for more than two decades surpassed the core coming second in the table only after Luxembourg.

The Western Balkans countries are desperate to join the European Union. If they do so they will be the fifth periphery of the European Union. The Balkans have always been the poorest part of Europe. Appeal of the wealthy European Union is apparent. Access to the largest market in the world, investment, modern technologies and generous regional funds give a hope that by joining the EU the Western Balkans countries will join the rich club.

At the moment performance of the Western Balkan countries does not guarantee that they will become rich by joining the European Union. Their current production and trade structure makes it likely that the Western Balkan countries will be locked in inter-industry trade in which they will export products of low and medium technological and developmental level and import products of high technological and developmental level. This might lead to divergence rather than convergence between them and the European Union. In other words, the Greek scenario is looming.

In other to overcome this problem the Western Balkan countries need to conduct radical reforms in the public sector, fiscal policy, industrial trade and investment policy. They also need to tackle corruption, simplify administrative procedure, strenghten property rights and the lawful state. All this with the aim to change economic structure and shift from achievements of the second and third to fourth technological revolution. Only if these reforms are successfuly implemented the Western Balkan countries can hope to avoid the Greek scenario and possibly experience the Irish scenario.

Apart from the former EFTA members (Iceland, Lichtenstein, Norway and Switzerland) and a few former republics of the Soviet Union (Bjelorussia, Moldova and Ukraina) the countries of the Western Balkans are the only European states outside of the European Union. They are very keen to join the Union. The Balkans have always been the poorest part of Europe. The appeal of the wealthy European Union is apparent. Access to the largest market in the world, investment, modern technologies and generous regional funds give a hope that by joining the EU the Western Balkans countries will join the rich club. 
At the moment performance of the Western Balkan countries does not guarantee that they will become rich by joining the European Union. Their current production and trade structure makes it likely that the Western Balkan countries will be locked in inter-industry trade in which they will export products of low and medium technological and developmental level and import products of high technological and developmental level. This might lead to divergence rather than convergence between them and the European Union. In other words, the Greek scenario is looming.

In other to overcome this problem the Western Balkan countries need to conduct radical reforms in the public sector, fiscal policy, industrial trade and investment policy. They also need to tackle corruption, simplify administrative procedure, strenghten property rights and the lawful state. All this with the aim to change economic structure and shift from achievements of the second and third to fourth technological revolution. Only if these reforms are successfuly implemented the Western Balkan countries can hope to avoid the Greek scenario and possibly experience the Irish scenario.

\section{REFERENCES}

[1] Larry Allen (2013) The Global Economic Crisis - a Chronology, Reaktion Books, UK

[2] Ilias Asseb (2019)The EU Core and Peripheries - Comparison between Belgium and Greece, unpublished project done at the SSST

[3]Richard Baldwin and Charles Wyplosz (2009)The Economics of European Integration - Third Edition, Mc Graw-Hill, London, p 80-83

[4] Roger Bootle (2014)The Trouble with Europe, Nicholas Brealey Publishing, London - Boston

[5]Vjekoslav Domljan (2014) Put u zaposlenost, Ekonomski Institut Sarajevo

[6] Vjekoslav Domljan (2018)Vitalni (N)racionalni interes, Lijepa riječ, Tuzla, p 56-58

[7]Azra Hadžiahmetović (2011) Ekonomija Evropske Unije, University Press Sarajevo

[8] Miroslav N Jovanović (2013)Economics of European Integration Second Edition, Edward Elgar, UK

[9] Costas Lapavitsas et al (2012)Crisis in the Euro Zone, Verso, London and New York, p 117 \& 118

[10] Marko Kos (1998)Trends in Development of Transition Countries, Characteristics and Possibilities of Slovenia in Comparison with Other Post-Communist Countries and the European Union

[11] Paul R Krugman, Maurice Obstfeld \& Marc J. Melitz (2015)International Economics - Theory and Policy - Tenth Edition, Pearson Education Limited

[12]Tahir Mahmutefendić (2015) The Great Recession, the Balkans and the Euro, Xlibris, p [13] taken from Larry Allen (2013), p210; taken from Costas Lapavitsas et.al. (2012), p 117 \& 118; taken from Roger Bootle (2012), p $95 \& 96$

[14] Tahir Mahmutefendić (2018)Balkanske tranzicijske i globalizacijske teme- eseji i prikazi, Lijepa riječ, Tuzla

[15] Tahir Mahmutefendić (2019)Kratak leksikon ekonomskih pojmova/A Short Lexicon of Economic Concepts, Markos Banjaluka

[16] George Petrakos and Stoyan Totev (editors) (2001)The Development of the Balkan Region, Ashgate Publishing Company Limited

[17] Brue Stanley L. \& Grant Randy R. (2013)The Evolution of Economic Thought - eight edition, South Western Cengage Learning, USA

[18] Max Veber (1972)Protestantska etika i duh kapitalizma, Veselin Masleša Sarajevo

[19] World Bank International Comparison Program Data 2019

[20] World Economic Outlook, IMF 2019 